\title{
A SURVEY OF RICE PRODUCTION AND PROCESSING IN SOUTH EAST NIGERIA
}

\author{
C. G. Okeke ${ }^{1, *}$ and S. I. Oluka ${ }^{2}$ \\ 1, 2 Dept. of Agric \& Bio. Engr. Enugu State University of SCiEnCE And Technology, EnUgu State, NigeriA. \\ E-mail addresses: 1 chinezeglory@yahoo.com, 2 ikeoluka@yahoo.com
}

\begin{abstract}
An assessment of rice production and processing in South-Eastern Nigeria was carried out by investigative survey approach. The survey was basically to ascertain the extent of mechanization applicable in the area to enable the agricultural policy makers device the modalities for improving rice production and processing in the area. According to the results obtained from the study, the planting period of rice in the area was mostly between May and August. Virtually 77\% of the farmers raise the rice seedlings in the nursery bed before transplanting to the permanent seed bed while 23\% sow the seeds directly to the seed bed where they germinate and grow to maturity. Results revealed that $75 \%$ of the farmers in the South-Eastern Nigeria use manual labour in the seed bed preparation while 25\% use tractors. It was observable from the results that 15-15-15 NPK and urea fertilizers were predominantly used by the farmers in the area for rice production and the application method was mostly by manual broad casting over the planted area. Results also recorded that rice harvesting mostly took place from October - December; and about 69\% of the farmers harvest their rice manually while $31 \%$ use mechanical means. More so, average of $49.6 \%$ of the farmers thresh their harvested rice manually while $50.4 \%$ of them use mechanized means. It was also observed that $93 \%$ of the farmers use both steam heating and total drenching method in parboiling the paddy rice while $3.4 \%$ and $3.6 \%$ use steam heating and total drenching respectively in parboiling the paddy rice. The milling method applicable in the area was mainly by mechanical means with $73.6 \%$ of the farmers who use the method while $10.4 \%$ of the farmers use manual method. The farmers generally use sacks in bagging and/or storing both the paddy and milled rice. Finally results showed that mechanization of rice production and processing has not received much attention as most of the farmers still use manual labour and traditional approach in the production and processing of rice.
\end{abstract}

Key words: Rice, mechanization, production, processing, bagging, south east Nigeria.

\section{INTRODUCTION}

Rice is a very important grain food to the world. The domestication and cultivation of rice is one of the most important events in our agricultural history. The only most important raw material needed for commercial production of rice is the rice seeds or seedlings [1]. Additional use of herbicides, pesticides and fertilizer can increase the likelihood of a larger yield. There are different varieties of rice according to the morphology and topography of the soil. Prior to planting, minimal soil preparations is needed to prepare for cultivation. If the rice will be grown on a hilly terrain, the area must be leveled into terraces. Field are leveled and surrounded by dikes or levels with the aid of earth-moving equipment depending on the size of farm, [2]

The cultivation of rice begins by preparing seed bed/ land preparation which includes land clearing, tillage, ploughing etc depending on size of farm. After land preparations, planting begins by planting either watersoaked rice or dry rice seeds. Seeds can be sown using a machine that places the seed in the soil in large farms but in developed countries low flying planes broadcast rice seeds onto already prepared fields. After one month or less of growth, the seedlings are transplanted in bunches from nursery beds to main field if it is not planted directly to the field. First weeding commences 1 month after transplanting or 21 days after germination for those planted directly to the field. Second weeding may be done 36 days after first weeding.

Prior to transplanting fertilizer may be broadcasted and puddle into the soil according to the farmers schedule. Some farmers may schedule for first top dressing or broadcasting 2-3 weeks after transplanting. Application of fertilizer depends on the farmers' schedule.

At maturity stage (approximately four months after planting) the grains begin to ripen, the tips begins to droop and the stem yellows - the water in the field is drained if it is a flooded field [3]. As the field dries up, the grains ripe further and harvesting is commenced. Depending on the size of the farm and the level of 
mechanization, rice is either harvested by mechanized means or manual labour. According to [4], 60\% of farmers in African uses manual labour. Threshing of rice follows the harvesting operation, but in a full mechanized system where rice is being harvested with rice combine, harvesting and threshing are done simultaneously with combine harvester.

After harvesting and threshing, the paddy rice is parboiled and milled using manual or mechanical method. Before milling, rice grain is dried in order to reduce the moisture content to about $19 \%$ to avoid breakage of the seeds during milling. The drying can be done through naturally occurring sunshine. In developed countries drying can be done with artificially heated air. Rice is processed at mill using automated processes. The paddy rice undergoes many processes like hulling, polishing, grading, destonning etc. before marketing or storage.

After Hulling which is removal of the outer huskto get the bran rice, polishing of the bran rice begins which is removal of the outer bran layer to get the white rice. Grading follows after polishing. Grading is separating long rice from broken rice. Destonning follows immediately after grading. Foreign rice at stage of polishing do undergo further processes which is also called coating i.e. coating with either protein material or any other substance [5]. This is generally known as converted rice. The production and processing of rice in South- Eastern Nigeria is mostly by traditional and/ or mechanized methods; the researcher tried to evaluate the system of rice production/processing in the area to ascertain the extent of mechanization applicable in the area.

Food shortage across the country demand adequate attention and/or assistance to the indigenous producers and processors of agricultural food materials in area of mechanization

Various agricultural wastes such as rice Straw, and Groundnut Husk have been used to produce bricks. Rice husk ash was used to treat the compressibility characteristics of black cotton soil as fillings for embankment [6].Rice is one of the most valuable staple food for large chunk of Nigerian population; but despite its nutritional and economic values; mechanization of its production and/or processing in some rural areas have not received much attention making the production, processing and even storage difficult for the local farmers. One major reason for the low level of output most times is low level of agricultural mechanization resulting from poor financial background of the farmers to procure farm machineries [7].

Knowledge of rice production and processing in SouthEastern Nigeria will ascertain the extent of mechanization applicable in the area and will enable government or agricultural policy makers device means of assisting the farmers in mechanizing the production and processing so as to boost their output. Farmers in the rural areas face difficulties in the production and processing of agro-foods because of lack of funds and their poor knowledge of newer methods applicable in land preparation/tillage, seed planting/sowing, fertilizer application, weed/pest control methods, irrigation or drainage method, harvesting, handling, processing and storage of their farm products. This study will be focused on the assessment of the rice production and processing in the South-Eastern agricultural zone of Nigeria to guide the governments, researchers, agricultural organizations and policy makers in adopting or devising means for ameliorating the difficulties encountered by the rice farmers thereby improving, boasting and/or mechanizing rice productions, processing and optimizing quality control in SouthEastern Nigeria.

The main aim of this study is to obtain data on rice production and processing applicable in South-Eastern Nigeria which will guide the government, agricultural policy makers and researchers in devising measures for improving/ mechanizing rice production and/or processing in the area and the specific objectives are: to determine various rice planting methods applicable in the area; to determine the method adopted by the farmers in applying fertilizers to the planted rice; to determine the methods used by the farmers in controlling weeds and pests in their rice farm; to determine the various rice harvesting and threshing methods applicable in Southern Eastern Nigeria and to ascertain the various methods adopted by the farmers in processing their paddy rice.

\section{MATERIALS AND METHODS}

\subsection{Description of the study area}

The study area is South-East agricultural zone of Nigeria comprising of Abia, Anambra, Ebonyi, Enugu and Imo States. It has a land area of approximately $28,972 \mathrm{~km}^{2}$ and the vegetation of the area is a mixture of savanna and tropical rainforest with average annual rain fall of $2500 \mathrm{~mm}$ [8]. South -East Nigeria has fertile and welldrained soil and the good population are essentially farmers.

\subsection{Samples for the study}

The samples for the study consist of 1000 rice farmers (200 from each state of the region) within the average farm size from 40 hectares and above selected randomly from the five states that make up south east region of Nigeria. 


\subsection{Questionnaire Administration / Data Collection}

Every information concerning rice production and processing, starting from land preparation to milling was collected from the farmers via the use of questionnaire.

Prior to the collection of information, some selected farmers were gathered through the village heads and cooperative farmers. The questionnaire was administered to them. In addition to information obtained from the questionnaires, the researcher visited various rice farms and two rice milling industries per state for more information about rice production and processing in the study area.

\section{RESULT AND DISCUSION}

\subsection{Results}

The results of this research work are analyzed using percentages and presented in descriptive statistical tables.

Table 1: Land preparation and methods of planting rice in South Eastern Nigeria

\begin{tabular}{|c|c|c|c|c|c|c|c|c|}
\hline \multirow[b]{2}{*}{ Study area } & \multirow[b]{2}{*}{$\begin{array}{l}\text { No of } \\
\text { questionnaire } \\
\text { retrieved }\end{array}$} & \multirow[b]{2}{*}{$\begin{array}{l}\text { Average } \\
\text { land area }\end{array}$} & \multicolumn{2}{|c|}{ System of propagation } & \multicolumn{2}{|c|}{ Land preparation } & \multicolumn{2}{|c|}{ Planting Method } \\
\hline & & & $\begin{array}{l}\text { (Nursery) } \\
\text { transplanting } \\
(\%)\end{array}$ & $\begin{array}{l}\text { (seed) Direct } \\
\text { planting (\%) }\end{array}$ & Manual (\%) & Mechanical (\%) & $\begin{array}{l}\text { Manual } \\
(\%)\end{array}$ & $\begin{array}{l}\text { Mechanical } \\
(\%)\end{array}$ \\
\hline Abia & 200 & 40 & 80 & 20 & 70 & 30 & 93 & 7 \\
\hline Anambra & 198 & 70 & 82 & 18 & 75 & 25 & 88 & 12 \\
\hline Ebonyi & 200 & 73 & 91 & 9 & 81 & 19 & 95 & 10 \\
\hline Enugu & 197 & 43 & 63 & 37 & 69 & 31 & 90 & 10 \\
\hline Imo & 200 & 41 & 69 & 31 & 80 & 20 & 90 & 5 \\
\hline \multicolumn{2}{|c|}{ Average } & 53.4 & 77 & 23 & 75 & 25 & 91.2 & 08.8 \\
\hline
\end{tabular}

Table 2: Post planting operations applicable in south eastern Nigeria

\begin{tabular}{|c|c|c|c|c|c|c|c|c|}
\hline \multirow[b]{2}{*}{ Study area } & \multicolumn{2}{|c|}{ Fertilizer application } & \multicolumn{2}{|c|}{ Weed control method } & \multicolumn{2}{|c|}{ Pest control methods } & \multicolumn{2}{|c|}{ Harvesting methods } \\
\hline & $\begin{array}{c}\text { Manual } \\
\text { broadcasting (\%) }\end{array}$ & $\begin{array}{c}\text { Mechanical } \\
\text { broadcasting (\%) }\end{array}$ & $\begin{array}{c}\text { Manual } \\
(\%)\end{array}$ & Mechanical.(\%) & $\begin{array}{c}\text { Manual } \\
(\%)\end{array}$ & Mechanical (\%) & $\begin{array}{c}\text { Manual } \\
(\%)\end{array}$ & Mechanical (\%) \\
\hline Abia & 90 & 10 & 8 & 92 & 8 & 92 & 70 & 30 \\
\hline Anambra & 89 & 11 & 6 & 94 & 10 & 90 & 40 & 60 \\
\hline Ebonyi & 92 & 8 & 20 & 80 & 22 & 78 & 75 & 25 \\
\hline Enugu & 80 & 20 & 7 & 93 & 17 & 83 & 80 & 20 \\
\hline Imo & 90 & 10 & 15 & 85 & 9 & 91 & 80 & 20 \\
\hline Average & 88.2 & 11.8 & 11.2 & 88.8 & 13.2 & 86.8 & 69 & 31 \\
\hline
\end{tabular}

Table 3: Timing of Threshing and Threshing Method

\begin{tabular}{|c|c|c|c|c|c|c|}
\hline \multirow[b]{2}{*}{ Study area } & \multirow[b]{2}{*}{$\begin{array}{l}\text { No of } \\
\text { respondents }\end{array}$} & \multirow[b]{2}{*}{$\begin{array}{c}\text { No of questionnaire } \\
\text { retrieved }\end{array}$} & \multicolumn{2}{|c|}{ Timing of threshing } & \multicolumn{2}{|c|}{ Threshing method } \\
\hline & & & $\begin{array}{c}\text { Begins } \\
\text { immediately after } \\
\text { cutting }\end{array}$ & $\begin{array}{l}\text { Delay after } \\
\text { cutting (\%) }\end{array}$ & Manual (\%) & Mechanical (\%) \\
\hline Abia & 200 & 200 & 85 & 15 & 43 & 57 \\
\hline Anambra & 200 & 98 & 50 & 50 & 30 & 70 \\
\hline Ebonyi & 200 & 200 & 80 & 20 & 40 & 60 \\
\hline Enugu & 200 & 97 & 75 & 25 & 45 & 55 \\
\hline Imo & 200 & 200 & 85 & 15 & 90 & 10 \\
\hline & Average & & 75 & 25 & 49.6 & 50.4 \\
\hline
\end{tabular}

Table 4: Process of Parboiling of the Paddy Rice

\begin{tabular}{|c|c|c|c|c|c|c|}
\hline \multirow[b]{2}{*}{ Study area } & \multirow{2}{*}{$\begin{array}{c}\text { No of } \\
\text { respondents }\end{array}$} & \multirow{2}{*}{$\begin{array}{c}\text { No of } \\
\text { questionnaire } \\
\text { Retrieved }\end{array}$} & \multicolumn{3}{|c|}{ Per boiling processes } & \multirow{2}{*}{$\begin{array}{l}\text { Average period of } \\
\text { soaking before } \\
\text { perboiling (hrs) }\end{array}$} \\
\hline & & & $\begin{array}{c}\text { Steam heating } \\
(\%)\end{array}$ & $\begin{array}{c}\text { Total drenching } \\
(\%)\end{array}$ & $\begin{array}{c}\text { Both practices } \\
(\%)\end{array}$ & \\
\hline Abia & 200 & 200 & 5 & 3 & 92 & 5 \\
\hline Anambra & 200 & 98 & 10 & 15 & 75 & 3 \\
\hline Ebonyi & 200 & 200 & - & - & 100 & 8 \\
\hline Enugu & 200 & 97 & - & - & 100 & 8 \\
\hline \multirow[t]{2}{*}{ Imo } & 200 & 200 & - & - & 98 & 4 \\
\hline & Average & & 3.0 & 3.6 & 93 & 5.6 \\
\hline
\end{tabular}


Table 5: Milling, Grading / Destoming and Bagging of Polished Rice

\begin{tabular}{|c|c|c|c|c|c|c|c|}
\hline \multirow{2}{*}{ Study area } & \multirow{2}{*}{ No of respondents } & \multirow{2}{*}{$\begin{array}{l}\text { No of questionnaire } \\
\text { retrieved }\end{array}$} & \multicolumn{2}{|c|}{ Milling method } & \multirow[t]{2}{*}{ Grading/ Destoning } & \multicolumn{2}{|c|}{ Bagging method } \\
\hline & & & Manual & Mechanised & & Sack & polythene \\
\hline Abia & 200 & 200 & 20 & 80 & 70 & 100 & 0 \\
\hline Anambra & 200 & 98 & 1 & 99 & 90 & 90 & 10 \\
\hline Ebonyi & 200 & 200 & 10 & 90 & 90 & 100 & 0 \\
\hline Enugu & 200 & 97 & 10 & 90 & 90 & 100 & 0 \\
\hline Imo & 200 & 200 & 11 & 89 & 80 & 100 & 0 \\
\hline & Average & & 10.4 & 73.6 & 84 & 98 & 2 \\
\hline
\end{tabular}

Table 6: ANOVA for table 9 for weed and pest control

\begin{tabular}{|c|c|c|c|c|c|c|c|}
\hline Total number of observations & 5 & & & & & & \\
\hline $\begin{array}{l}\text { Manual weed control method = } \\
200.0000-1.0000 * \text { Chemical } \\
\text { weed control method }\end{array}$ & & & & & & & \\
\hline ANOVA & & & & & & & \\
\hline & d.f. & SS & MS & $\mathrm{F}$ & p-level & & \\
\hline Regression & 1 & 587.2 & 587.2 & 0 & \#N/A & & \\
\hline Residual & 3 & $3.34 \mathrm{E}-27$ & $1.11 \mathrm{E}-27$ & & & & \\
\hline Total & 4 & 587.2 & & & & & \\
\hline & Coefficients & $\begin{array}{l}\text { Standard } \\
\text { Error }\end{array}$ & $\mathrm{LCL}$ & UCL & t Stat & $\begin{array}{l}\mathrm{p}- \\
\text { level }\end{array}$ & $\begin{array}{l}\mathrm{H} 0(0.1 \%) \\
\text { rejected? }\end{array}$ \\
\hline Intercept & 200 & $2.45 \mathrm{E}-13$ & 200 & 200 & 8.17E+14 & 0 & Yes \\
\hline Chemical weed control method & -1 & $1.38 \mathrm{E}-15$ & -1 & -1 & $-7.3 \mathrm{E}+14$ & 0 & Yes \\
\hline $\mathrm{T}(0.1 \%)$ & 12.92397864 & & & & & & \\
\hline
\end{tabular}

Table 7: Normality Tests for timing of trashing and trashing method

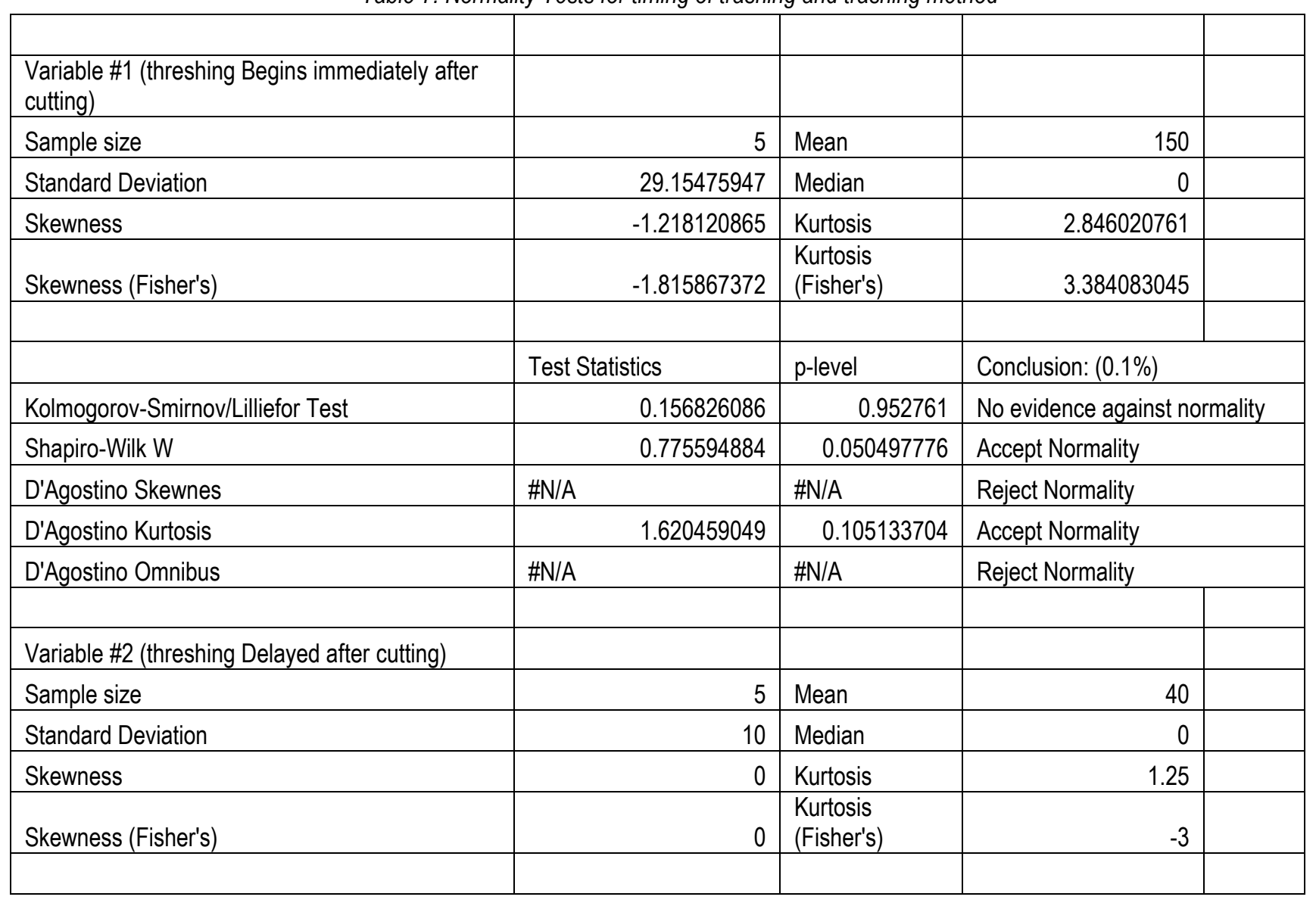




\begin{tabular}{|c|c|c|c|}
\hline & Test Statistics & p-level & Conclusion: $(0.1 \%)$ \\
\hline Kolmogorov-Smirnov/Lilliefor Test & 0.158655294 & 0.947304038 & No evidence against normality \\
\hline Shapiro-Wilk W & 0.820834672 & 0.118509894 & Accept Normality \\
\hline D'Agostino Skewness & $\# N / A$ & $\# N / A$ & Reject Normality \\
\hline D'Agostino Kurtosis & -1.57447727 & 0.115377152 & Accept Normality \\
\hline D'Agostino Omnibus & $\# N / A$ & $\# \mathrm{~N} / \mathrm{A}$ & Reject Normality \\
\hline \multicolumn{4}{|c|}{ Variable \#3 (Manual method of threshing) } \\
\hline Sample size & 5 & Mean & 99.2 \\
\hline Standard Deviation & 46.61759325 & Median & 0 \\
\hline Skewness & 1.26117952 & Kurtosis & 2.98802078 \\
\hline \multirow[t]{2}{*}{ Skewness (Fisher's) } & 1.880055426 & $\begin{array}{l}\text { Kurtosis } \\
\text { (Fisher's) }\end{array}$ & 3.952083119 \\
\hline & Test Statistics & p-level & \multirow{2}{*}{$\begin{array}{l}\text { Conclusion: }(0.1 \%) \\
\text { Sufficient evidence against } \\
\text { normality }\end{array}$} \\
\hline Kolmogorov-Smirnov/Lilliefor Test & 0.378223301 & 0.018416228 & \\
\hline Shapiro-Wilk W & 0.776730176 & 0.051655565 & Accept Normality \\
\hline D'Agostino Skewness & $\# N / A$ & $\# N / A$ & Reject Normality \\
\hline D'Agostino Kurtosis & 1.862476682 & 0.062535929 & Accept Normality \\
\hline D'Agostino Omnibus & $\# N / A$ & $\# N / A$ & Reject Normality \\
\hline \multicolumn{4}{|c|}{ Variable \#4 (Mechanical method of threshing ) } \\
\hline Sample size & 5 & Mean & 100.8 \\
\hline Standard Deviation & 46.61759325 & Median & 0 \\
\hline Skewness & -1.26117952 & Kurtosis & 2.98802078 \\
\hline \multirow[t]{2}{*}{ Skewness (Fisher's) } & -1.880055426 & $\begin{array}{l}\text { Kurtosis } \\
\text { (Fisher's) }\end{array}$ & 3.952083119 \\
\hline & Test Statistics & p-level & Conclusion: $(0.1 \%)$ \\
\hline Kolmogorov-Smirnov/Lilliefor Test & 0.200206498 & 0.732961292 & No evidence against normality \\
\hline Shapiro-Wilk W & 0.776730176 & 0.051655565 & Accept Normality \\
\hline D'Agostino Skewness & $\# N / A$ & $\# N / A$ & Reject Normality \\
\hline D'Agostino Kurtosis & 1.862476682 & 0.062535929 & Accept Normality \\
\hline D'Agostino Omnibus & $\# N / A$ & $\# N / A$ & Reject Normality \\
\hline
\end{tabular}

Table 8: ANOVA analysis for process of parboiling of paddy rice

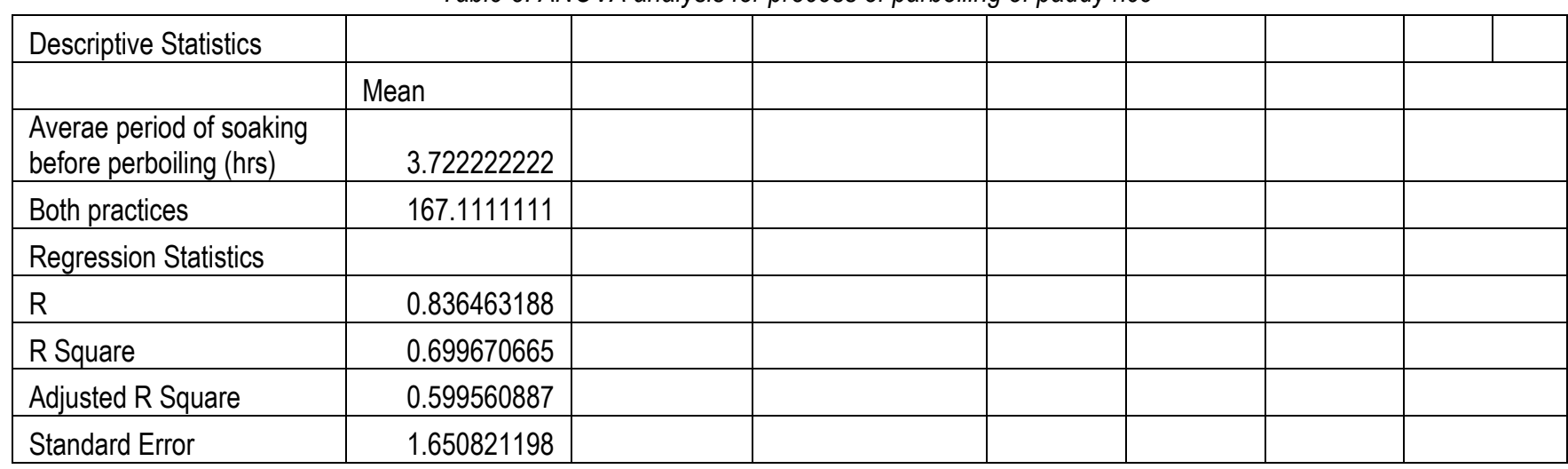




\begin{tabular}{|c|c|c|c|c|c|c|c|}
\hline $\begin{array}{l}\text { Total number of } \\
\text { observations }\end{array}$ & 5 & & & & & & \\
\hline \multicolumn{8}{|c|}{$\begin{array}{l}\text { Averae period of soaking before perboiling (hrs) }=-2.5052+ \\
0.0373^{*} \text { Both practices }\end{array}$} \\
\hline \multicolumn{8}{|l|}{ ANOVA } \\
\hline & d.f. & SS & MS & $\mathrm{F}$ & p-level & & \\
\hline Regression & 1 & 19.04659034 & 19.04659034 & 6.989034 & 0.077412 & & \\
\hline Residual & 3 & 8.175631886 & 2.725210629 & & & & \\
\hline \multirow[t]{3}{*}{ Total } & 4 & 27.22222222 & & & & & \\
\hline & & & & & & & \\
\hline & Coefficients & $\begin{array}{l}\text { Standard } \\
\text { Error }\end{array}$ & $\mathrm{LCL}$ & UCL & t Stat & p-level & $\begin{array}{l}\mathrm{HO}(0.1 \%) \\
\text { rejected? }\end{array}$ \\
\hline Intercept & -2.505184705 & 2.371598189 & -33.15566903 & 28.1453 & -1.05633 & 0.36836 & No \\
\hline Both practices & 0.037265068 & 0.014095917 & -0.144910263 & 0.21944 & 2.643678 & 0.077412 & No \\
\hline $\mathrm{T}(0.1 \%)$ & 12.92397864 & & & & & & \\
\hline \multicolumn{8}{|l|}{ ANOVA } \\
\hline & d.f. & SS & MS & $\mathrm{F}$ & p-level & & \\
\hline Regression & 1 & 27733.24734 & 27733.24734 & 16.47073 & 0.026964 & & \\
\hline Residual & 3 & 5051.368049 & 1683.78935 & & & & \\
\hline Total & 4 & 32784.61538 & & & & & \\
\hline
\end{tabular}

Table 9: ANOVA Method of milling, destonning and bagging

\begin{tabular}{|c|c|c|c|c|c|c|c|}
\hline \multicolumn{8}{|c|}{$\begin{array}{l}\text { Weighted Least Squares Regression for method } \\
\text { of milling }\end{array}$} \\
\hline \multicolumn{8}{|l|}{ Descriptive Statistics } \\
\hline & Mean & & & & & & \\
\hline Grading/ Destoning & 160.3846154 & & & & & & \\
\hline Mechanised milling & 172.2307692 & & & & & & \\
\hline \multicolumn{8}{|l|}{ Regression Statistics } \\
\hline $\mathrm{R}$ & 0.919740511 & & & & & & \\
\hline R Square & 0.845922608 & & & & & & \\
\hline Adjusted R Square & 0.794563477 & & & & & & \\
\hline Standard Error & 41.03400236 & & & & & & \\
\hline Total number of observations & 5 & & & & & & \\
\hline \multicolumn{8}{|c|}{$\begin{array}{l}\text { Grading/ Destoning }=-120.0794+1.6284 \text { * } \\
\text { Mechanised milling }\end{array}$} \\
\hline \multicolumn{8}{|l|}{ ANOVA } \\
\hline & d.f. & SS & MS & $\mathrm{F}$ & p-level & & \\
\hline Regression & 1 & 27733.24734 & 27733.24734 & 16.47073 & 0.026964 & & \\
\hline Residual & 3 & 5051.368049 & 1683.78935 & & & & \\
\hline \multirow[t]{2}{*}{ Total } & 4 & 32784.61538 & & & & & \\
\hline & Coefficients & $\begin{array}{l}\text { Standard } \\
\text { Error }\end{array}$ & $\mathrm{LCL}$ & UCL & t Stat & p-level & $\begin{array}{l}\mathrm{HO} \\
(0.1 \%) \\
\text { rejected? }\end{array}$ \\
\hline Intercept & 120.0794351 & 69.22383017 & 1014.726737 & 774.5679 & -1.73465 & 0.181212 & No \\
\hline Mechanised milling & 1.628420124 & 0.401245318 & 3.557265788 & 6.814106 & 4.058415 & 0.026964 & No \\
\hline $\mathrm{T}(0.1 \%)$ & 12.92397864 & & & & & & \\
\hline
\end{tabular}




\begin{tabular}{|c|c|c|c|c|c|c|c|}
\hline $\begin{array}{l}\mathrm{LCL} \text { - Lower value of a reliable } \\
\text { interval ( } \mathrm{LCL})\end{array}$ & & & & & & & \\
\hline $\begin{array}{l}\text { UCL - Upper value of a reliable } \\
\text { interval (UCL) }\end{array}$ & & & & & & & \\
\hline $\begin{array}{l}\text { Linear Regression for bagging } \\
\text { method }\end{array}$ & & & & & & & \\
\hline $\begin{array}{l}\text { Warning(s): } \\
\text { GLM Error: Error in computing } \\
\text { variance estimate! }\end{array}$ & & & & & & & \\
\hline Error in estimating std.err. of a $\mathrm{B}$ & & & & & & & \\
\hline Regression Statistics & & & & & & & \\
\hline $\mathrm{R}$ & 1 & & & & & & \\
\hline R Square & 1 & & & & & & \\
\hline Adjusted R Square & 1 & & & & & & \\
\hline$S$ & 0 & & & & & & \\
\hline Total number of observations & 5 & & & & & & \\
\hline $\begin{array}{l}\text { Sack bagging method }=200.000 \\
\text { polythene Baging }\end{array}$ & 1.0000 * & & & & & & \\
\hline ANOVA & & & & & & & \\
\hline & d.f. & SS & MS & $\mathrm{F}$ & p-level & & \\
\hline Regression & 1 & 320 & 320 & 0 & $\# N / A$ & & \\
\hline Residual & 3 & 0 & 0 & & & & \\
\hline Total & 4 & 320 & & & & & \\
\hline & & & & & & & \\
\hline & Coefficients & $\begin{array}{l}\text { Standard } \\
\text { Error }\end{array}$ & $\mathrm{LCL}$ & UCL & t Stat & p-level & $\begin{array}{l}\mathrm{H} 0 \\
(0.1 \%) \\
\text { rejected? }\end{array}$ \\
\hline Intercept & 200 & \#N/A & $\# \mathrm{~N} / \mathrm{A}$ & \#N/A & $\# N / A$ & $\# \mathrm{~N} / \mathrm{A}$ & $\# N / A$ \\
\hline polythene Baging & -1 & $\# \mathrm{~N} / \mathrm{A}$ & $\# \mathrm{~N} / \mathrm{A}$ & $\# \mathrm{~N} / \mathrm{A}$ & $\# N / A$ & $\# \mathrm{~N} / \mathrm{A}$ & $\# \mathrm{~N} / \mathrm{A}$ \\
\hline$T(0.1 \%)$ & 12.92397864 & & & & & & \\
\hline
\end{tabular}

\subsection{Discussion}

The percentage values provides information on the level at which the South - Eastern Nigerian farmers are operating in rice production and processing.

Table 1 provides information on the rice planting methods and period of planting that is applicable the various states that made up the South-Eastern Nigeria. Results of this table revealed that the farmers generally use manual labour in seed bed or land preparation with Ebonyi State having the highest average percentage value of $81 \%$ followed by Imo and least is Enugu state with percentage values of 80 and $69 \%$ respectively. It is also observable from the results that most of the farmers (77\% in the study area raise their rice in the nursery bed before transplanting to the permanent seed bed where they grow to maturity while $23 \%$ of the farmers plant directly to the permanent seed bed. According to the farmers, both methods are good but the method of raising rice in the nursery before transplanting to the permanent seed bed seem to be faster in production.
Generally, the planting period is between May and August.

Table 2 revealed that virtually all the farmers in the study area use organic and inorganic fertilizers (15-1515 NPC, Urea and animal dung) in the production of rice; and the application period according to the results obtained is always 3 weeks ( 21 days) after planting. the method of fertilizer application applicable in the study area is mostly manual broadcasting method with Ebonyi State recording the highest at percentage value of manual labour (92\%), followed by Imo and Abia States with the same value of $90 \%$ respectively and least is Enugu with $80 \%$ manual labour utilized in fertilizer applications.

Tables 2 also show the method of weed and pests control methods applicable in the study area. From the results as presented in these tables, it is observed that the farmers generally use chemical and manual means to control weeds and pests in their rice farms. But the use of chemical method in both operation (weed and pest control) outweighed the manual means. Remarkably 
88.8\% use chemical means to control the weed and $86.8 \%$ also use chemicals for pest control; while $11.2 \%$ and $13.2 \%$ respectively use manual labour in controlling weeds and pests.

Table 2 shows the time and method of harvesting adopted by rice farmers in the study area. Results of this table indicated that the harvesting period of rice is between October and December under normal circumstances. Manual harvesting methods are predominantly used in the area with Enugu and Imo recording the highest percentage manual labour of $80 \%$ respectively and Anambra having the least of $40 \%$ manual labour utilized in harvesting.

Table 3 presents information on the method of rice threshing used by the farmers after harvesting. According to the results obtained, with manual and mechanized methods are used in the study area in threshing rice. Observations revealed that manual and mechanized method generally stored $49.6 \%$ and $50.4 \%$ respectively in rice threshing with Imo State having almost $90 \%$ in using mechanical means in threshing their rice.

Table 4 presents the result of parboiling process of the paddy rice. The result shows that Ebonyi State and Enugu State use both total drenching of the paddy and steam heating while Anambra and Abia use the three practices. Ebonyi and Enugu State also has the highest soaking periods which is about 8 hours

Table 5 represents the milling, grading/destoning and bagging of polished rice. All the state use mechanical means of milling though they all needs modern machines. Enugu, Ebonyi and Anambra States do total destoning and grading followed by Imo State though in some part of Anambra they do destoning without doing grading. All the states uses sacks in bagging but some farmers in Anambra put polythene bags inside of the sac bag before bagging of the rice to avoid liquid penetration.

Table 6, 7, 8 and 9 present the ANOVA of the weed, pest control, timing of threshing/threshing method, process of parboiling the paddy rice and milling/destoning/ bagging method. From the result of the analysis, the methods statistically accepted normality except for manual approach which is most times limited in supply and causes drudgery.

\section{CONCLUSION AND RECOMMENDATION}

The average land area used in South Eastern Nigeria for rice production is approximately 53.1ha with Ebonyi State having the largest land area followed by Anambra state.

Mechanization of rice production and processing in South-Eastern Nigeria has not received much attention as virtually every stage in its production and processing process are mostly by manual or traditional method.
Based on the above findings the following recommendations can be made to ameliorate the situation:

1. Government should provide grants, loans and subsides to rice farmers in the area to enable them cope and probably procure the machines that can be used in production and processing of rice instead of manual labour.

2. There should be public enlightenment in form of workshops and seminars through which the farmers should be educated on the new methods for improving agriculture and/or rice production and processing in the area.

3. Mechanized method of agriculture at every stage of production and processing should be introduced to the farmers in the area and other areas with similar agricultural crises to enable them boost up/or improve on their rice production and /or processing.

4. More researches should be carried out to ascertain more other challenges confronting rice farmers in the area so that adequate solutions and assistance can be proffered in order to improve their agricultural operations.

\section{REFERENCES}

[1] California's Rice Growing Region". California Rice Commission. Archived from the original on February 10, 2006. Retrieved August 10, 2007.

[2] Climate Change Ready Rice. International Rice Research Institute (IRRI). Retrieved October 31, 2013. Archived January 1, 1970, at the Wayback Machine.

[3] Jahn, G. C., Almazan, L. P., Pacia, J. B., Effect of Nitrogen Fertilizer on the Intrinsic Rate of Increase of Hysteroneura setariae (Thomas) Homoptera: Aphididae). 2005.

[4] FAOSTAT: Production-Crops, Data: Food and Agriculture Organization of the United Nations, 2014.

[5] National Research Council. African Rice. Lost Crops of Africa: Volume I: Grains. Lost Crops of Africa I. National Academies Press. 1996

[6] Akinyele J. O, Olateju O.T and O. K. Oikelome O.K ., Rice husk as filler in the production of bricks using gboko clay. Nigerian Journal of Technology Vol. 34 No. 4, October 2015 , pp. $672-678$

[7] Oduma, O., Eze, P.C and Igboke, M.E., Survey of operators' knowledge of operation and maintenance of farm machinery in Ebonyi state, Nigeria. Nigerian Journal of Technology, Vol. 33 No. 4, October2014, pp. $559-565$

[8] Ezemonye, M. N. and Emeribe, C. N. Rainfall erosivity in Southeastern Nigeria. Ethiopian Journal of Environmental Studies and Management, 2012. 5 (2), 112- 122 . 